\title{
LETRAMENTO LITERÁRIO E CONSTITUIÇÃO ESTÉTICA EM UMA EXPERIÊNCIA COM "PÁSSAROS", DE RINALDO DE FERNANDES
}

\author{
Antonio Naéliton do Nascimento ${ }^{1}$ \\ Márcia Tavares ${ }^{2}$ \\ Roberto Barbosa Costa Filho ${ }^{3}$
}

\begin{abstract}
Resumo: Refletir sobre experiências de ensino que têm o texto literário como norte propicia investigar esse espaço de aprendizagem de modo a ampliá-lo e (res)significá-lo. Nesse sentido, apresentamos uma experiência de ensino de Literatura no âmbito de estágio supervisionado dos anos finais do Ensino Fundamental, analisando uma proposta de leitura para o conto "Pássaros", de Rinaldo de Fernandes, e a recepção alcançada por esta com os alunos de uma turma de 9o ano. Fundamentamo-nos, para isso, em Candido (1995) e em Cadermartori (1986) sobre acepções de Literatura; em Jauss (1979) e Iser(1996) sobre conceitos e pressupostos da estética da recepção, e em Cosson (2006) sobre letramento literário. De modo significativo, percebemos que, nas práticas de linguagem em sala de aula, o ensino de Literatura não deve levar em consideração somente especificidades conceituais (linguístico-textuais e os elementos da narrativa), mas reconhecer a complexidade deste gênero literário, contemplando, no processo de leitura do conto, as várias dimensões interpretativas, estilísticas, como também de cunho social ao envolver temas de interesse dos alunos, aspectos que foram acionados no contato com o gênero selecionado a partir da leitura compartilhada e do debate realizados em sala de aula.
\end{abstract}

Palavras-chave: Letramento literário. Ensino de Literatura. Rinaldo de Fernandes. Estágio Supervisionado.

\section{Introdução}

O espaço concedido às aulas de literatura é, ainda hoje, objeto de discussão e investigação entre professores e pesquisadores relacionados ao ensino de Língua Portuguesa. A abordagem nos livros didáticos e nas escolas parece ainda estar muito vinculada ao ensino de gramática e, em relação à literatura, privilegia-se, muitas vezes, mais as especificidades conceituais do que a experiência de leitura com o próprio texto literário. Com isso, perde-se de vista o fator mais importante do processo, o texto literário, que é o objeto sobre o qual deve haver um trabalho sistemático quanto à sua fruição e seu ensino.

Para Candido (1995), a literatura é um poderoso instrumento de educação que, ao fazer parte dos currículos, compartilha discussões sobre os valores sociais estabelecidos, assim como os vícios prejudiciais à formação humana.

\footnotetext{
${ }^{1}$ Graduando em Letras - (UFCG). Bolsista de PIBIC/UFCG.

2 Doutora em Letras - Professora do PPGLE/UAL/UFCG

3 Graduando em Letras - (UFCG). Bolsista PIBIC/UFCG
} 
Além disso, "a literatura confirma e nega, propõe e denuncia, apoia e combate, fornecendo a possibilidade de vivermos dialeticamente os problemas" (CANDIDO, 1995, p. 177). Sob essa perspectiva podemos vislumbrar o potencial transformador que a literatura tem nesse processo de humanização a partir da leitura e por meio do contato com o mundo sob a ótica literária.

Os documentos oficiais já sinalizaram a importância de se trabalhar com a literatura na sala de aula, como os Parâmetros Curriculares Nacionais (PCN), no âmbito dos quais se defendia um trabalho com o texto literário que estivesse "incorporado às práticas cotidianas da sala de aula, visto tratar-se de uma forma específica de conhecimento" (BRASIL, 1998, p. 29). Portanto, desde os PCN havia uma preocupação quanto ao ensino, ainda que não houvesse uma visibilidade adequada para o texto de natureza literária. Com a Base Nacional Comum Curricular (BRASIL, 2017), vinte anos depois, temos uma transição no ensino fundamental de uma visão de literatura que excede a condição de objeto de ensino e passa a ser um campo ${ }^{4}$ de estudos, no qual se devem realizar práticas de linguagem orais, escritas, multissemióticas e de leitura, todas voltadas ao trabalho com os textos literários. Segundo o documento, deve-se investir "em práticas de leitura literária que possibilitem o desenvolvimento do senso estético para a fruição, valorizando a literatura e outras manifestações artístico-culturais [...], reconhecendo o potencial transformador e humanizador da experiência com a literatura" (BRASIL, 2017, p. 87).

Com isso, vemos que tais documentos destacam a relevância de se abordar de forma apropriada, considerando os vieses temático-culturais e estético-formais do texto literário em contexto de sala de aula. Assim, reconhecendo a complexidade envolvida na didatização desse texto, temos como objetivo, neste trabalho, apresentar uma experiência de ensino de Literatura no âmbito de um estágio supervisionado nos anos finais do Ensino Fundamental, analisando uma proposta de leitura para o conto "Pássaros", de Rinaldo de Fernandes, e a recepção alcançada com alunos de uma turma de 9aa.

\footnotetext{
${ }^{4}$ A BNCC de Ensino Fundamental (anos finais), no que se refere ao ensino de Língua Portuguesa, traz quatro campos de estudos: campo artístico-literário, campo das práticas de estudo e pesquisa, campo jornalístico-midiático e campo de atuação na vida pública.
} 
É com base numa confluência de paradigmas, assim como de (re)construção da prática educativa, que o estágio ocorreu: trazendo textos cuja receptividade fosse efetiva por parte dos alunos e que estes pudessem experimentar a linguagem literária, explorando os aspectos desde a arquitetura textual, aos modos singulares de cada autor e como isso refletiria na construção da narrativa. Nesse sentido, a utilização do texto literário vem a serviço da fruição, do ponto de vista estético, e da reflexão linguística, pois "o preenchimento dos vazios do texto é feito pelo leitor que supre os diferentes graus de indeterminação da escrita" (CADERMARTORI, 1986, p. 83).

Desse modo, a fim de cumprir com o objetivo ora apresentado, este texto divide-se, além desta introdução, em seções nas quais: i) discutem-se aspectos voltados ao entendimento da posição do leitor na construção dos sentidos do texto literário a partir dos pressupostos teóricos da Estética da Recepção de Iser (1996), considerando a teoria do efeito estético e os vazios do texto, e as teses de Jauss (1994) sobre horizonte de expectativa do leitor, assim como as definições sobre o Letramento Literário, fundamentadas nas exposições de Rildo Cosson (2006), entre outros; ii) apresentam-se questões relevantes sobre o gênero conto, bem como um sucinto comentário do texto literário escolhido para proposta de leitura, agregando a estética singular do autor escolhido; iii) analisa-se e reflete-se sobre a experiência e a recepção alcançada pelos alunos considerando nossa base teórica; e iv) apresentam-se as considerações finais.

\section{Em busca do letramento literário: pressupostos teóricos à formação de leitores}

É senso comum que a iniciação à leitura crítica requer o domínio de operações intelectuais abstratas, da formação da personalidade e da percepção afetiva e intelectual do indivíduo. Os critérios de escolha das obras ofertadas aos alunos deveriam levar em consideração uma parcela do sistema de leitura que pudesse atender ao que interessa ao leitor nessa fase, que pudesse provocar novos conhecimentos, discussões e posicionamentos diante de textos que aguçam o senso estético e lúdico dos contratos de ficção nas narrativas e dos jogos de sonoridade dos poemas. No entanto, o que ocorre no ensino 
fundamental e médio, e desemboca no ensino superior, é uma prática irregular de leitura, como uso cotidiano de uma abordagem de leitura que se pauta muitas vezes no pragmatismo de identificação do gênero e/ou do historicismo literário, em que há pouca preocupação por temas de interesse do aluno e que, consequentemente, seu universo de expectativa corre o risco de não ser atendido. $O$ entendimento do papel do leitor na construção do significado do texto está fundamentado nos estudos da Estética de Recepção de Hans Robert Jauss e Wolfgang Iser. Os dois autores provocam, na Universidade de Constança no ano de 1967, as discussões e, de forma abrangente, desenvolvem a premissa da valorização do leitor como pólo ativo na construção dos sentidos dos textos. Os teóricos da estética da recepção consideram o leitor como o receptor capaz de reconstruir, interferir e trazer outros significados para o texto ficcional. É ele quem preenche na obra o que o autor deixou como espaço vazio. O autor, quando cria, desenvolve com o tema o que interessa ao leitor e faz uso de vários recursos para pautar sua narrativa e sua visão do mundo. Hans Robert Jauss, defende que:

a relação entre literatura e leitor possui implicações tanto estéticas quanto históricas. A implicação estética reside no fato de que a recepção primária de uma obra pelo leitor encerrar uma avaliação de seu valor estético, pela comparação com outras obras já lidas. A implicação histórica manifesta-se na possibilidade de, numa cadeia de recepções, a compreensão dos primeiros leitores ter continuidade e enriquecer-se de geração em geração, decidindo, assim, o próprio significado histórico de uma obra e tornando visível sua qualidade estética. (JAUSS, 1994 apud RIBEIRO, 2011, p. 21.)

Para Jauss o leitor tende a trazer para a realidade fatos de textos ficcionais, assim como transportar para a ficção fatos de textos que se dizem históricos, dependendo do entendimento real que ele carrega em seu repertório, mediante leituras feitas em outras obras em que ele adquiriu conhecimento para acionar em novas leituras. As premissas da Estética da Recepção que organiza as instâncias do autor e do leitor estão estabelecidas nas teses expostas por Jauss. A primeira tese aborda a historicidade literária, já que coincide com a atualização da obra literária, pois para cada obra lida, no momento da leitura, as reflexões do leitor estão presentes pelos fatores literários que os relacionam com os fatos vividos ou lidos por ele, em situações favoráveis para sua recepção. $\mathrm{Na}$ 
segunda tese o estudioso cria a expressão horizonte de expectativa que motiva a recepção. Segundo o autor, o leitor real participa ativamente da obra conforme seu horizonte de expectativa relacionado com o da obra através das experiências trazidas por ele no ato da leitura. A terceira tese relaciona-se com maneira como o texto pode atender ao horizonte de expectativas do leitor ou provocar desconfiança e rompimento deste horizonte de expectativa. A distância entre as expectativas do leitor e sua realização é denominada por Jauss de "distância estética" (JAUSS, 1994, apud RIBEIRO, 2012, p. 22). A quarta tese de Jauss sugere algumas relações contemporâneas do texto com a época de sua publicação. Esta tese preocupa-se em descobrir como o leitor da época percebe e compreende a obra literária, restaurando o processo de comunicação que se estabeleceu, no momento em que a obra foi lançada. Na quinta o teórico aborda o efeito diacrônico, uma vez que no momento da leitura o texto deve dialogar com outras leituras já feitas. Na sexta tese Jauss abre espaço para o aspecto sincrônico que para ele é muito relevante para a compreensão do leitor num período específico da historiografia literária. A última destaca a relação entre literatura e sociedade por acreditar que esta relação literária ajuda a formar a concepção de mundo do leitor, refletindo então em seu comportamento social.

Por sua vez, estabelecendo os fundamentos da teoria do efeito estético, Wolfgang Iser defende que existe uma interação entre o texto e o leitor e aponta que "o papel do leitor resulta da interação de perspectivas e se desenvolve na atividade orientada de leitura" (ISER, 1996, p. 75). Segundo Iser essa interação é uma condição do processo de comunicação entre o texto literário e o leitor, pois é por meio dele que a obra se comunica. Diferentemente de Jauss que concentra em seus estudos o entorno da recepção da obra, Iser destaca o efeito que o texto causa, ressaltando a ponte que se estabelece entre o texto detentor e suas propriedades - o texto literário, com sua ênfase nos vazios deixados. Portanto, a recepção de uma obra é medida pelo destinatário através das experiências trazidas por ele no ato da leitura, ao passo que o efeito dessa obra estaria ligado à interação texto/leitor.

Para Iser (1996, p. 73), o texto literário contém "vazios" que, durante o ato da leitura, levam o leitor a compreendê-lo. Essas situações implícitas são fundamentais no processo de interação, pois representam as quebras das 
conexões textuais e apontam ao leitor quais partes devem ser conectadas de acordo com o seu ponto de vista. Portanto, o preenchimento dessas lacunas é uma ação comunicativa que se materializa na interação do leitor com o texto, sendo ela a reação ou a resposta que ocorre a partir da leitura. Iser defende em sua teoria do efeito estético que tanto os textos como o leitor têm um repertório de conhecimento e de normas sociais, estéticas e culturais que fazem sua interação no momento da leitura. Essa interação, segundo o teórico, é enunciada por um leitor implícito que aguça a imaginação do leitor real e permite-lhe uma projeção interpretativa no ato da leitura.

O leitor implícito não tem existência real, mas é uma estrutura do texto que pode ser regulada por uma espécie de jogo que favorece a interação entre o texto e o leitor. Para Iser (1996, p.73), "uma estrutura que projeta a presença do receptor". Desse modo, o leitor implícito não é uma simples abstração, ele leva pelo meio do ato imaginativo do leitor real as diferentes formas deste leitor interpretá-lo. De acordo com o teórico, a realização do papel do leitor implícito acontece mediante atos imaginativos nos quais lhe são dados caráter transcendental à obra literária. Nesse sentido, o esquema descrito do papel do leitor é uma estrutura do texto. Mas, como estrutura textual, o papel do leitor representa, sobretudo, uma intenção que apenas se realiza através dos atos imaginativos estimulados no receptor. Assim entendidos, a estrutura do texto e o papel do leitor estão intimamente unidos. (ISER, 1996, p. 75.)

O leitor, na tentativa de dar respostas às questões referentes a acontecimentos vividos no instante da leitura, remete a uma significação para o sentido (significado). O sentido estabelecido no texto pelo leitor é resultado de uma atividade basicamente social ainda que tenha como produto final a atualização do objeto estético na consciência do leitor, que permanecerá em seu plano individual e representacional

Para Cosson (2006, p. 16), esse leitor real responde ainda, junto a essas solicitações psicológicas e à influência ideológica do texto, através das solicitações e impactos no corpo, uma vez que "o corpo linguagem, o corpo palavra, o corpo escrita encontra na literatura seu mais perfeito exercício". Nesse sentido, conforme o autor, o uso da palavra é posta em um lugar que supera, em todos os aspectos, a atividade de codificação, para dar vazão à (re)construção do 
mundo e de suas relações. A experiência propiciada pela/na literatura, com isso, permite a quem lê compreender o mundo por meio da visão do outro, da qual passa a fazer parte e a ressignificá-la. Diante desse papel humanizador, e em meio a todo o construto caótico da atual sociedade, o direito à literatura torna-se uma necessidade cada vez mais urgente. Em sala de aula, como bem observa Barbosa (2011), esse direito

\begin{abstract}
implica que aqueles que se dedicarão à formação desse tipo de leitor tenham antes compreendido que a literatura é indispensável, porque transgride o senso comum, porque nos desloca, permitindo um olhar diferente para o mundo, porque nos faz descobrir o que não pensávamos existir, inclusive em nós. O potencial formador da literatura é garantia de autonomia e liberdade. (BARBOSA, 2011, p. 153).
\end{abstract}

Compreendemos, pois, a importância da literatura no ambiente escolar, em todas as fases de escolarização. Nesse sentido, acreditamos que a leitura literária deva ser "exercida sem o abandono do prazer, mas com o compromisso de conhecimento que todo saber exige." (COSSON, 2006, p. 23). Desse modo, é importante que se desenvolvam práticas que se centrem na leitura efetiva dos textos, de modo que nem se restrinjam a informações críticas, historiográficas e teorias, nem que se tornem um caminho assistemático sem mediação, uma vez que a literatura deve cumprir um papel nesse ambiente.

$\mathrm{Na}$ experiência que apresentamos neste trabalho, tivemos como objetivo o desenvolvimento do letramento literário nas turmas em atuação, por meio das experiências proporcionadas pela leitura dos textos literários. De acordo com Cosson (2006), o princípio do letramento literário é "a construção de uma comunidade de leitores" (COSSON, 2006, p. 47), de modo a possibilitar a formação de um repertório de textos, através de um "ensino da Literatura [que] efetive um movimento contínuo de leitura, partindo do conhecido para o desconhecido, do simples para o complexo, do semelhante para o diferente, com o objetivo de ampliar e consolidar o repertório cultural do aluno" (COSSON, 2006, p. 47-48).

Por meio da fixação da prática efetiva do letramento literário em sala de aula e do acesso cada vez maior a textos literários, criar-se-á, muito provavelmente, uma aproximação com a obra literária que favorece ao leitor o 
despertar para a prática da leitura por escolha própria, a fim de descobrir novas experiências e pelo próprio prazer estético (BARBOSA, 2011). Isso permite também com que a leitura seja aperfeiçoada, possibilitando, conforme Borges e Paes (2017, p. 257), "ler não só o que está apresentado na superfície do texto, mas, consegue-se realizar uma leitura profunda (nas entrelinhas), e, é essa leitura que proporciona o olhar crítico que desagrega do texto, todos os pormenores inseridos no texto [...]". Dessa forma, a proficiência leitora a que se pode atingir em sala de aula não somente beneficiará o ensino da Língua Portuguesa e da Literatura, mas tornará o aluno apto a lidar com situações, cada vez mais recorrentes, que exijam a criticidade ao ler textos. Esse construto alia-se à perspectiva de vivência com o texto literário, com a experiência de leitura primordialmente, e com a experimentação de respostas e o movimento de ida e vinda ao texto que favorecem a construção do sentido.

Elegemos, para construção do repertório de textos literários, o gênero conto, por ser uma narrativa curta e por "trabalhar em profundidade, verticalmente, seja para cima ou para baixo do espaço literário" (CORTÁZAR, 2006, p. 152), o que faz com que nada no texto seja gratuito ou decorativo, mas tenha significância para 0 todo narrado, conforme explanaremos na próxima seção.

\section{0 gênero conto: da conceituação a "Pássaros", de Rinaldo de Fernandes}

Considerado a mais antiga expressão da literatura, bem como a mais generalizante (cf. MAGALHÃES JÚNIOR, 1972), o conto tem suas origens na oralidade, como forma encontrada pelos povos para transmissão de estórias. $\mathrm{Na}$ escrita, suas primeiras aparições constituíam-se no registro escrito dessas estórias. Somente a posteriori é que se passou à criação do conto por escrito, atribuindo a um narrador a função de contar. (GOTLIB, 1990).

Comparando o conto a uma fotografia, Cortázar (2006, p. 151) apresenta um paradoxo que compreende a ambas as formas artísticas: "de recortar um fragmento da realidade, fixando-Ihe determinados limites, mas de tal modo que esse recorte atue como uma explosão que abre de par em par uma realidade muito mais ampla". Com isso, conforme o autor, tem-se que no conto, assim como na fotografia, o seu criador buscará, nos limites que lhes são impostos pela 
extensão a capturar, destacar elementos que sejam significativos, a fim de atuarem como "aberturas" para lançar a inteligência e a sensibilidade do apreciador a algo muito maior do que o texto ou a imagem podem expor.

Nessa direção, "o tempo e o espaço do conto têm de estar como que condensados, submetidos a uma alta pressão espiritual e formal para provocar essa "abertura"” (CORTÁZAR, 2006, p. 152). Além disso, como pontua Magalhães Júnior (1972), a psicologia envolta nos personagens e as motivações para suas ações dão-se pela conduta dos próprios personagens. Isso ressalta o grau de importância de cada elemento trazido à narrativa para a construção do elo de significação do texto, de modo que tais elementos, ao fazerem parte do horizonte de expectativas do leitor, auxiliam-o na construção de sentidos.

O conto brasileiro contemporâneo incorporou diversas modificações promovidas por uma estética herdada de várias fontes, inclusive do movimento modernista. Enquanto a maioria das narrativas anteriores a década de 1920 se prendia à estrutura tradicional de começo, meio e fim, construindo um enredo que objetivava um relato linear e convencional dos fatos, o conto moderno abandonou essa estrutura e surpreendeu o leitor com a suspensão da narrativa, cortes abruptos em meio às ações e predomínio de diálogos, entre outros recursos. As inovações e mudanças ocorreram de forma constante e em um longo período, mas, a partir do final da década de 1940, a prosa moderna brasileira foi impulsionada pela exploração das linguagens do homem comum, a contemplação intimista marcada pelo fluxo da consciência e a descrição por meio de instantâneo fotográfico entre outras faces adotadas pelos escritores dessa fase. Dessa maneira, os contistas pretendiam configurar a vida moderna sob novas perspectivas, e assim os contos foram se multiplicando em novas denominações e diversificando suas formas de representação do real urbanizado.

Nesse cenário, o paraibano Rinaldo de Fernandes, segundo Gama (2012) é nome de grande repercussão na contística urbanista da literatura brasileira contemporânea. Segundo a autora, os recursos mais constantes em seus contos são: "o condicionamento dos personagens a um contexto sociocultural opressor; a incursão de poesia na narrativa; o amor que sucumbe diante da frieza, indiferença, traição e do egoísmo; e presença de animais e sua simbologia pertinente" (GAMA, 2012, p. 19). 
Em Pássaros, da obra Contos Reunidos, (2016) conto elegido para a experiência ora apresentada, temos uma narrativa em $1^{\text {a }}$ pessoa, sendo através do ponto de vista do personagem-narrador, Roberto, que conhecemos o que se passa na estória, ou seja, temos acesso aos acontecimentos com certa parcialidade do que esse personagem considera importante de ser revelado e por meio de seus valores éticos e modos de enxergar o mundo. $O$ enredo, iniciado em ambiente urbano, trata de uma relação amorosa aparentemente desgastada entre Roberto e Márcia, com sequências que se voltam à violência entre ambos, não sendo apresentadas motivações de forma clara ao leitor para isso. Inicialmente, temos que Roberto pensa em matar a companheira, talvez por uma traição, como interpretativamente possibilitado pelo trecho: "de dentro do carro, debaixo da árvore, vi o teu beijo nele [o professor] ali no bar da orla". Todavia, não há condições de afirmar essa traição, uma vez que não são dados detalhes sobre esse beijo, podendo ser este simplesmente de cumprimento, o que nos leva a uma segunda possibilidade: o ciúme. O personagem, contudo, não executa o plano por passar por momentos de aparente remorso e tristeza.

A narrativa tem uma reviravolta quando descobrimos que Márcia também guardava planos de matar o companheiro, provavelmente por ter descoberto, primeiro, o plano deste, como é possível observar em: "- Você não soube me enganar, Roberto", sendo esse o momento de clímax da narrativa. O seu desfecho, porém, apresenta a morte de Márcia, não pelas mãos do excompanheiro, mas vítima de um atropelamento por uma camionete que se desgovernou na estrada, representando, como dito pelo próprio personagemnarrador, cenas de um "filme pobre".

O texto é construído com períodos curtos e diretos, em que cada elemento apresentado contribui para transmissão da tensão ao leitor. Explorando ao máximo as pistas sugestivas do texto, a narrativa de Fernandes abre várias possibilidades interpretativas por ser uma obra aberta. Como elementos simbólicos, os pássaros, diante disso, são bastante metaforizados, alimentados por uma espécie de sublimação dos personagens na narrativa. Aparecem em momentos de tensão e constroem para o leitor pistas ao longo do texto. Após esses dados de leitura, veremos a seguir como se deu a experiência e a recepção desse conto em sala de aula. 


\section{Refletindo sobre leitura literária: Uma proposta a partir de "Pássaros"}

A experiência de estágio, da qual surge nossa proposta de leitura, teve como horizonte o (re)fazer-se docente. A metodologia e o planejamento utilizados, embora definidos, abriram-se à flexibilização, visto que sabemos que a escola é um espaço em que forças sociais internas e externas (LIBÂNEO, 2008) atuam sobre a prática docente. $\mathrm{E}$, em se tratando do trabalho com o texto literário, não há fórmulas prontas, nem receitas para serem reproduzidas: é preciso um olhar sensível para saber conduzir os caminhos para onde a literatura pode levar.

Nesse sentido, o nosso planejamento pode ser entendido como "uma sucessão de etapas que se desencadeiam numa sequência lógica, obedecendo normas, métodos e técnicas específicas para atingir algumas finalidades, metas e objetivos" (MENEGOLLA e SANT'ANNA, 2014, p. 16), cuja execução levou em consideração as especificidades do gênero e da esfera de que faz parte. $\mathrm{Na}$ construção da proposta de estágio, a ser descrita posteriormente, foram considerados conteúdos factuais, procedimentais, atitudinais (ZABALA, 1998), a fim de superar o ensino estritamente propedêutico de Língua Portuguesa, pautado apenas na gramática tradicional e numa visão unilateral da Literatura, sobretudo se pensado no nível de ensino fundamental.

Dessa forma, buscamos dar visibilidade à narrativa curta. A partir disso, escolhemos o gênero suspense para ser trabalhado, uma vez que 0 consideramos alinhado aos gostos dos adolescentes, tendo em vista que, na maioria das vezes, são jovens cujas "preferências literárias giram em torno de fatos da atualidade, ficção científica, histórias policiais e de fantasmas, onde predominam o sensacionalismo, a violência, as gangues e os vilões" (AGUIAR, 1985, p. 100).

Dentre as atividades desenvolvidas durante o estágio, optamos por analisar uma delas, cujo envolvimento dos alunos pareceu ser mais significativo, sobretudo em relação às discussões orais, pois suscitou debate acerca da temática. Como já foi sinalizado, o conto Pássaros, de Rinaldo de Fernandes, traz uma discussão que atravessa várias questões éticas/morais do âmbito social, de uma forma tensa e ágil, com uma linguagem acessível aos alunos, se tratando, ainda, de literatura paraibana. 
Optamos por levar aos alunos um texto de um autor paraibano por dois motivos: em primeiro lugar, por ser uma linguagem mais próxima à realidade dos alunos; e, em segundo lugar, porque anteriormente foi trabalhado um conto de Edgar Allan Poe, "Barril de Amontillado", cuja linguagem é bem diferente do fazer literário de Rinaldo, fazendo com que se pudesse observar, em contos escritos em épocas e contextos diferentes, como o suspense se manifesta em narrativas e como pode ser (re)construído. Atendemos assim aos pressupostos, anteriormente apresentados, da Estética da recepção expostos na discussão sobre o horizonte de expectativas do leitor e a realização e o rompimento desses, entendida como a "distância estética" abordada por Jauss (1996).

Nesse encontro, constituído de duas aulas, foi realizada uma leitura compartilhada, de modo que os alunos pudessem ter o primeiro contato com o texto literário em pauta. Após a leitura, propôs-se uma atividade aos alunos (ver apêndice 1), a partir da qual eles pudessem depreender as formas de construção do suspense, assim como fazer a comparação com os outros contos já lidos. Para isso, dividiu-se a turma em pequenos grupos, os quais ficariam com uma pergunta a ser respondida e, depois, as respostas seriam socializadas na roda de discussão. Com isso, nos ancoramos num dos preceitos da BNCC sobre ensino de literatura e escolhas metodológicas, segundo o qual

diferentes gêneros, estilos, autores e autoras - contemporâneos, de outras épocas, regionais, nacionais, portugueses, africanos e de outros países - devem ser contemplados; o cânone, a literatura universal, a literatura juvenil, a tradição oral, o multissemiótico, a cultura digital e as culturas juvenis, dentre outras diversidades, devem ser consideradas (BRASIL, 2017, p. 157).

Assim, enxergamos nessa proposta de leitura literária uma possibilidade de interlocução maior entre texto-leitor, dando a possibilidade de os alunos ampliarem seu repertório linguístico-literário, a partir de diferentes linguagens e dos mais variados contos. Após essa leitura, foi realizada a atividade em grupo, que consistia em fazer com que os alunos, primeiro, pudessem discutir entre si as questões, para depois socializar com os colegas, a fim de que pudesse haver uma troca colaborativa de opiniões, materializadas em práticas orais e escritas conforme a atividade propunha. A escolha pela leitura compartilhada deu-se, 
principalmente, porque "a literatura faz com que o leitor não se sinta um receptor passivo, mas seja partícipe da aventura de viver e de criar, co-inventor de seu mundo e co-narrador da história." (YUNES, 2010, p. 61). Assim, conduzindo a discussões sobre os vários aspectos da narrativa, como questões voltadas ao narrador, o principal foco da aula, os alunos opinaram e refletiram sobre as conclusões a que chegaram após a leitura.

Essa perspectiva de ensino de literatura dialoga com o pressuposto de que "é preciso supor - e, portanto, garantir a formação de - um leitor-fruidor, ou seja, de um sujeito que seja capaz de se implicar na leitura dos textos, de "desvendar" suas múltiplas camadas de sentido, de responder às suas demandas e de firmar pactos de leitura" (BRASIL, 2017, p. 138). Portanto, vemos que é sob uma metodologia de desmontagem do texto literário que a proposta se organizou, fazendo com que os alunos pudessem firmar um pacto de leitura, consistente e envolvido, com o texto que possui possibilidades inesgotáveis de significação.

A atividade proposta visava à "concretização, a materialização da interpretação como ato de construção de sentido" (COSSON, 2006, p. 65). Desse modo, as perguntas feitas buscavam refletir sobre o conto lido, fazendo com que o aluno mobilizasse habilidades de comparação sobre a linguagem e estilo do autor, quando associadas a leituras feitas anteriormente, de modo que a interpretação levasse os alunos a exteriorizarem suas experiências de leitura.

Em face a essa metodologia de experienciação do conto, cabe mostrar, então, a recepção dos alunos quanto à narrativa, que pode ser observada em algumas respostas dadas aos questionamentos sobre o conto. Iser (1996) defende, em sua teoria do efeito estético, que tanto os textos como o leitor têm um repertório de conhecimento e de normas sociais, estéticas e culturais que fazem sua interação no momento da leitura. Essa interação, segundo o teórico, pode ser enunciada pelos vazios do texto, uma vez que a construção dos sentidos favorece uma projeção interpretativa no ato da leitura.

Dentre as respostas, selecionamos três, um conjunto diverso e que expõe a heterogeneidade de opiniões esperada numa discussão em torno de textos literários, sobretudo em função da plurrissignicação do gênero. A primeira resposta que escolhemos é um tanto mais geral, pois se refere à metáfora dos pássaros, que aparece sinalizada no título do conto, sobre o qual se questionou 
como essa imagem aparece no texto e o que ela significaria. Como resposta, temos a figura 1 :

Figura 1 - Significado dos pássaros

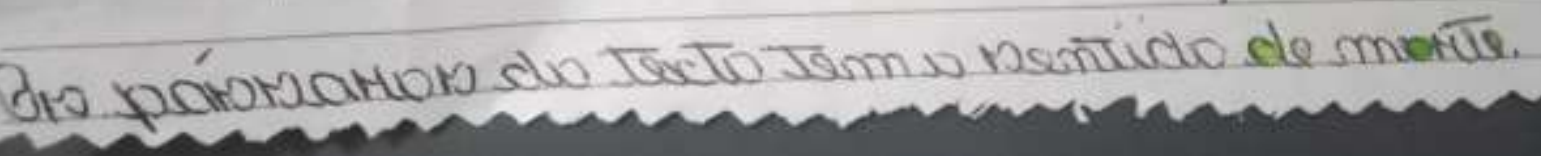

Fonte: arquivos do estágio.

A partir da resposta acima, vemos que os pássaros são tomados, para o grupo que ficou responsável por discutir internamente essa pergunta, como símbolos da morte. É uma concepção singular, visto que, durante todo o texto, os pássaros acompanham o estado de espírito do narrador (que ora está com ânsia de vingança, ora mais triste). Como no final do conto temos uma morte, esses pássaros, cuja espécie não é revelada, podem assumir várias formas e ter vários significados, desde uma conotação de liberdade, de voo para espíritos aprisionados, como também uma significação mais mórbida, posto que a morte é o destino final do conto.

Com isso, vemos que explorar uma metáfora central do conto pode revelar muito acerca de toda a narrativa. A segunda pergunta, mais específica, buscou conjugar inter-relações com os outros contos já lidos, perguntando em que se aproximam as linguagens entre os autores, posto que um dos objetivos era observar como o suspense pode se constituir de diferentes formas ou até de maneiras semelhantes, conforme podemos atestar na resposta apresentada na imagem 2 a seguir:

Figura 2 - Comparação entre linguagens dos autores

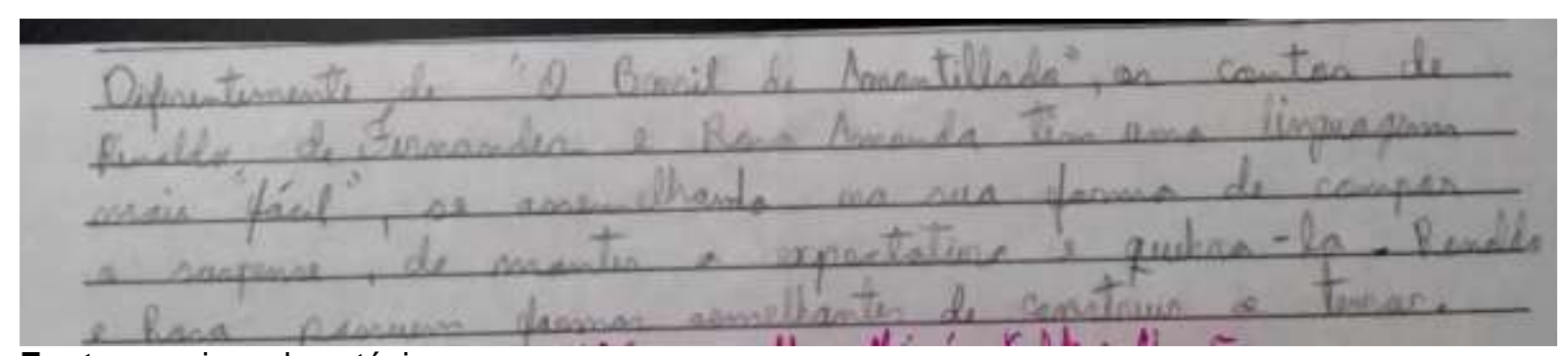

Fonte: arquivos do estágio. 
Com isso, vemos que o grupo em questão fez a relação entre o conto "Pássaros" e os outros já lidos, apontando as semelhanças entre dois deles quanto à linguagem menos formal, "mais fácil", como eles mesmos disseram, sobretudo com uma forma parecida de se construir o suspense, gerar expectativa e quebrá-la - uma "fórmula" clássica de construir contos de suspense. Por outro lado, apontam notadamente a diferença destes em relação ao conto de Edgar Allan Poe, que possui uma linguagem mais rebuscada e, portanto, "mais difícil". Uma pergunta dessa natureza tem como objetivo conduzir o aluno a perceber que são as especificidades de estilo do autor que (re)constroem os sentidos do texto, posto que é na leitura que o sujeito ativo supre os diferentes graus de indeterminação da escrita (CADERMARTORI, 1986), isto é, o texto não é senão um produto da interação entre leitor-texto. Assim, espera-se que o aluno, a partir dessa problematização, possa comprovar a riqueza do texto literário e que este não se limita apenas ao exercício de identificação dos elementos da narrativa.

Por fim, a última resposta que escolhemos tem um caráter mais polêmico, sobretudo em função da pergunta que questiona se a reação do narradorprotagonista frente à situação (de querer dar um tiro na namorada porque a viu beijando um rapaz num bar de uma orla) é justificável. A resposta foi tão polêmica quanto à pergunta, conforme podemos perceber na figura 3 abaixo:

Figura 3 - Reação do narrador protagonista

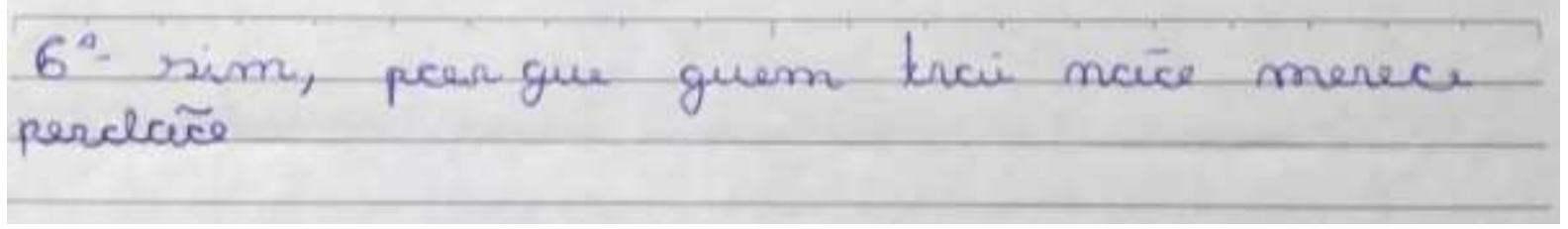

Fonte: arquivos do estágio.

Como podemos observar, a pergunta e a resposta controversas colocam em pauta um tema polêmico: violência com as próprias mãos. Parece ser consenso, ao grupo em pauta, que a violência justifica-se para os casos em que não se deve conceber o perdão, posto que a mulher merecia sofrer pelo fato de ter traído o namorado. Como objeto de transfiguração da realidade, a literatura 
consegue trazer à tona valores morais daqueles que, ao lerem um texto, se identificam com ele, exteriorizando suas opiniões.

Depois de feita a atividade, na socialização/debate de ideias, foi possível haver uma troca colaborativa de experiências sobre a leitura do conto, momento no qual se problematizou a resposta da figura 3. A pergunta foi feita com 0 objetivo de que os alunos percebessem minimamente duas coisas: em primeiro lugar, que a violência contra o outro é injustificável; em segundo lugar que, sendo o protagonista também o narrador, suas opiniões pessoais e sentimentos não podem tornar a visão das coisas totalmente confiável, pois esse narradorprotagonista descreve sob a sua ótica. Esses raciocínios foram contemplados pelos outros grupos, no momento da socialização das respostas, parte em que todos puderam passar por um processo de negociação dos sentidos do texto, como também por uma discussão ética a respeito dos (sub)temas que percorrem a narrativa.

Assim, vemos a importância de questionamentos sobre o texto literário que possibilitem ir além do domínio superficial. A socialização do texto literário, sem limitá-lo apenas à estrutura, conseguiu trazer a tona as diversas dimensões que emergem do processo de significação do conto, fazendo com que os sujeitos refletissem sobre a realidade, associassem às suas experiências pessoais, assim como pudessem (re)pensar valores, problematizar questões de ordens diversas, visto que a literatura consegue ampliar os horizontes de compreensão do mundo.

\section{Considerações finais}

Diante da experiência de estágio, entendemos que "leitor e texto ligam-se na medida em que o texto é uma organização simbólica com uma função representativa que se cumpre no leitor, pois a leitura é parte determinante de qualquer texto" (CADERMARTORI, 1986, p. 82). Assim, vemos que o texto só existe a partir da construção de sentidos que seu leitor agrega, ou seja, uma atividade dessa natureza mobiliza saberes, transforma e leva o aluno a diferentes épocas e experiências a partir do mundo da linguagem literária. Ademais, esta experiência, no âmbito de um estágio, suscita um olhar para o (re)fazer-se docente, que pode ser percebido no planejamento, execução e análise da 
atuação, sendo um importante instrumento de revisão de valores e atitudes por parte do sujeito (professor) em formação.

Primeiramente, cabe dizer que nossa atividade está em consonância com a proposta curricular mais recente, a Base Nacional Comum Curricular (BNCC), mostrando que é possível ressignificar o trabalho docente de uma perspectiva mais formal a uma passível de ser trabalhada em sala de aula. Em segundo lugar, percebemos como é possível fazer um trabalho que possa ir além de aspectos estruturais da narrativa e que não reduza a complexidade de significação do conto a apenas uma categorização de conceitos. Mais do que isso, percebemos que é no âmbito da troca e negociação de sentidos do texto literário que podemos problematizar a natureza humana, repensar valores, ampliar nossa visão interpretativa e de mundo.

Tendo isto em consideração, entendemos que o conto não é um objeto estático: o trabalho com ele suscita abordagens que dão conta das diversas dimensões que apresenta, fazendo-se necessário estimular a interlocução entre os alunos e o texto literário, posto que este é um objeto complexo e multifacetado. Ademais, entendemos que a literatura é um meio pelo qual o ser humano pode atingir um maior nível de compreensão de si mesmo e do mundo. Portanto, é preciso conceder, nas escolas, um espaço significativo às práticas de linguagem emanadas da literatura, visto que tal manifestação da arte atravessa todas as culturas, em todos os tempos e, sobretudo, porque tem como horizonte a humanização, um aspecto caro nos dias atuais em tempos tão desumanos.

\title{
LITERARY LITERACY AND AESTHETICS IN AN EXPERIENCE WITH "PÁSSAROS”, FROM RINALDO DE FERNANDES
}

\begin{abstract}
To reflect about teaching experiences in which have the literary text as a guide provide investigate this learning context in a way of expand it and (re)signify it. By this mean, we present a Literature teaching experience in the supervised internship in the final years of Middle School, analyzing a reading proposal to the short story "Pássaros", from Rinaldo de Fernandes and the achieved reception by it with the students from 8th grade. In order to achieve the aims, we base this study on Candido (1995) and on Cadermartori (1986) regarding Literature meaning; on Jauss (1979) and Iser (1996) regarding Reception Aesthetics concepts and assumptions; and on Cosson (2006) regarding Literary Literacy. In a meaningful way, we realized that, in the language practices inside the classroom, the Literature teaching should not only take into consideration conceptual specifications (linguistic-textual and narrative elements), but recognize the complexity of this literary genre, considering, in the short story reading process, the various interpretative dimensions, stylistics, as well as social stamp in involving themes of interests to the students,
\end{abstract}


aspects that were added with the contact with the selected genre from the shared reading and the debate realized in the classroom.

Key-words: Literary literacy. Literature teaching. Rinaldo de Fernandes. Supervised Internship

\section{Referências}

AGUIAR, V. T. Leituras para o $1^{\circ}$ grau: critérios de seleção e sugestões. In: ZILBERMAN, Regina (org.). Leitura em crise na escola: as alternativas do professor. 5. ed. Porto Alegre: Mercado Aberto, 1985, p. 85-105.

BARBOSA, Begma T. Letramento Literário: sobre a formação escolar do leitor jovem. Educ. foco, Juiz de Fora, v. 16, n. 1, p. 145-167, mar./ago. 2011.

BORGES, Igor A. B. G.; PAES, Fábio S. Leitura e literatura: o letramento literário como possibilidade de intelectualização. Aedos, Porto Alegre, v. 9, n. 21, p.244264, dez. 2017.

BRASIL. Base Nacional Comum Curricular: Educação Infantil e Ensino Fundamental. Brasília: MEC/Secretaria de Educação Básica, 2017.

BRASIL/MEC. Parâmetros Curriculares Nacionais - Terceiro e Quarto Ciclos do Ensino Fundamental: Língua Portuguesa. Brasília: MEC/SEF, 1998.

CADERMARTORI, Ligia. O que literatura infantil. São Paulo: Brasiliense, 1986.

CANDIDO, Antonio. Vários escritos. $3^{\mathrm{a}}$ ed. revista e ampliada. São Paulo: Duas Cidades, 1995.

CANDIDO, Antonio. A educação pela noite e outros ensaios. São Paulo: Ática, 1989.

CORTÁZAR, Julio. Alguns aspectos do conto e do conto breve e seus arredores. In: CORTÁZAR, Julio. Valise de cronópio. Trad. Davi Arrigucci Jr. e João Alexandre Barbosa. São Paulo: Perspectiva, 2006.

COSSON, Rildo. Letramento literário: teoria e prática. São Paulo: Contexto, 2006.

GAMA, Glória Maria Oliveira, Escrita Masculina/Personagens Femininas: Os Contos de Rinaldo de Fernandes. Tese de Doutoramento Programa de PósGraduação em Letras da Universidade Federal da Paraíba. 2012, 174 p. http://www.cchla.ufpb.br/ppgl/wp-

content/uploads/2013/06/images_pdf_GLORIA.pdf

FERNANDES, Rinaldo de. Contos reunidos. Barueri, SP: Novo Século Editora, 2016.

GOTLIB, Nádia B. Teoria do conto. São Paulo: Ática, 2006. 
ISER, Wolfgang. $O$ ato da leitura: uma teoria do efeito estético. Trad. Johannes Kretschermer. São Paulo: Ed.34, 1996

JAUSS, Robert Hans. A literatura e o leitor. Rio de Janeiro: Paz e Terra, 1979.

JOUVE, Vincent. A leitura. Trad. de Brigitte Hervor. São Paulo: Editora UNESP, 2002.

LIBÂNEO, J. C. Alguns aspectos da política educacional do governo lula e sua repercussão no funcionamento das escolas. HISTEDBR On-line, Campinas, n.32, p. 168-178, dez. 2008.

MAGALHÃES JÚNIOR, R. Origem e natureza do conto. In: MAGALHÃES JÚNIOR, R. $A$ arte do conto: sua história, seus gêneros, sua técnica, seus mestres. Rio de Janeiro: Bloch, 1972.

MENEGOLLA, Maximiliano; SANT'ANNA; Ilza Martins. Por que planejar? Como planejar? Currículo - área - aula. 22.ed. Petrópolis-RJ: Vozes, 2014.

RIBEIRO, Valdir Guilherme Alves. Recepção literária: a interação entre o texto literário e o leitor. 2011. 73 f. Dissertação (Mestrado em Comunicação, Linguagens e cultura) - Universidade da Amazônia, Belém - Pará.

YUNES, E. Leitura como experiência. In: YUNES, E.; OSWALD, M. L. (org.). A experiência da leitura. São Paulo: Edições Loyola, 2010. p. 7-16.

ZABALA, Antoni. A prática educativa: como ensinar. Porto Alegre-RS: Artmed, 2010.

\section{Apêndices}

Apêndice 1 - Questões que suscitaram o debate sobre o conto Pássaros, de Rinaldo de Fernandes

1. Rosa Amanda Strausz, autora do conto "Sete ossos e uma maldição", e Rinaldo de Fernandes, autor do conto "Pássaros", produzem uma literatura contemporânea, isto é, atual. Nos contos lidos, como a linguagem desses autores se aproxima?

2. Há algo do conto Pássaros que recorde o conto "Barril de Amontillado", de Edgar Allan Poe? Justifique.

3. Considerando o título do conto de Rinaldo de Fernandes, quais seriam os sentidos dos pássaros que aparecem ao longo da narrativa? 
4. A partir dos diálogos entre o casal no conto de Rinaldo de Fernandes, como você julga a relação amorosa deles?

5. Como você interpreta a afirmação "tudo ocorreu como filme pobre"?

6. Releia o trecho:

"Eu estava decidido que te daria um tiro desde o momento em que saímos do shopping, quando topamos com o professor (de dentro do meu carro, debaixo da árvore, vi o teu beijo nele ali no bar da orla)".

A reação dele é justificável frente ao que ele viu?

7. Releia o trecho:

"Eu então me voltei. E vi. Vi o meu revólver na tua mão (ainda agora fico pensando como você o descobriu no porta-malas)."

Como você julga a reação da personagem Márcia?

8. Após a leitura do último parágrafo, você acredita no arrependimento do personagem protagonista?

Data da Submissão:14/11/2019

Data da Aprovação: 27/12/2019 